\title{
PENGARUH MODEL PEMBELAJARAN MAKE A MATCH BERBANTUAN MEDIA AUDIO VISUAL TERHADAP KOMPETENSI PENGETAHUAN IPA
}

\author{
Mahayu Fahza Aulia ${ }^{1}$, I Nengah Suadnyana ${ }^{2}$ \\ 1,2, Jurusan Pendidikan Dasar, Universitas Pendidikan Ganesha, Singaraja, Indonesia \\ e-mail: mahayu.fahza.aulia@undiksha.ac.id ${ }^{1}$,inengahsuadnyana@undiksha.ac.id ${ }^{2}$
}

\begin{abstract}
ABSTRAK
Penelitian ini bertujuan untuk mengetahui pengaruh model pembelajaran Make $A$ Match berbantuan media Audio Visual terhadap kompetensi pengetahuan IPA kelas IV SD Gugus III Kuta Utara tahun ajaran 2018/2019. Penelitian ini adalah penelitian eksperimen semu dengan desain nonequivalent control group design. Populasi dari penelitian ini adalah seluruh kelas IV SD Gugus III Kuta Utara tahun ajaran 2018/2019 sebanyak 518 siswa. Sampel diambil dengan teknik random sampling. Sampel dalam penelitian ini yaitu sebanyak kelas IV SD No. 2 Kerobokan sebagai kelompok eksperimen dan sebanyak kelas IV A SD No. 1 Kerobokan Kaja sebagai kelompok kontrol. Data kompetensi pengetahuan IPA dikumpulkan menggunakan tes objektif dengan bentuk pilihan ganda biasa. Selanjutnya data dianalisis dengan menggunakan uji-t. Hasil analisis menunjukkan harga $t_{\text {hitung }}=5,128>t_{\text {tabel }}$ $=2,000$ pada taraf signifikansi $5 \%$ dengan $\mathrm{dk}=70$ sehingga terdapat perbedaan yang signifikan kompetensi pengetahuaan IPA kelompok yang dibelajarkan model pembelajaran Make A Match berbantuan media Audio Visual dengan kelompok yang dibelajarkan secara konvensional pada kelas IV SD Gugus III Kuta Utara tahun ajaran 2018/2019. Demikian pula rata - rata gain skor ternormalisasi kelompok eksperimen lebih dari rata - rata kelompok kontrol $(0,52>0,32)$. Dengan demikian dapat disimpulkan bahwa model pembelajaran Make A Match berbantuan media Audio Visual berpengaruh terhadap kompetensi pengetahuan IPA kelas IV SD Gugus III Kuta Utara tahun ajaran 2018/2019. Berdasarkan hasil penelitian ini dapat digunakan sebagai referensi untuk melaksanakan penelitian selanjutnya atau menemukan inovasi kegiatan pembelajaran lainnya yang bermakna bagi siswa.
\end{abstract}

Kata Kunci : Make A Match, Audio Visual, Kompetensi Pengetahuan IPA

\begin{abstract}
This research aimed to determine the effect of the learning model Make A Match assisted by Audio Visual on science knowledge competencies of IV Grade on SD Gugus III Kuta Utara academic year 2018/2019. This research is a quasi-experimental research with a design of nonequivalent control group design. The population of this research were all class IV SD Gugus III Kuta Utara academic year 2018/2019 as many as 518 students. The sample is taken by random sampling technique. The sample in this research is as much as class IV SD No. 2 Kerobokan as an experimental group and as many as class IV A SD No. 1 Kerobokan Kaja as control group. Knowledge science competency data was collected using objective tests with ordinary multiple choice forms. Then the data were analyzed using the $\mathrm{t}$ test. The results of the analysis show that the price of tcount $=5.128>$ ttable $=2,000$ at the significance level of $5 \%$ with $\mathrm{dk}=70$ so that there is a significant difference in the group's science competency taught by the learning model Make A Match assisted by Audio Visual with the group taught conventionally in grade IV SD Gugus III Kuta Utara academic year 2018/2019. Similarly, the average gain of the normalized experimental group score was more than the average of the control group (0.52> 0.32). Thus it can be concluded that the learning model Make A Match assisted by Audio Visual influences the fourth grade science competency of SD Gugus III Kuta Utara academic year 2018/2019. Based on the results of this research it can be used as a reference to carry out further research or find other innovative learning activities that are meaningful to students.
\end{abstract}

Keywords : Make A Match, Audio Visual, Science Knowledge Competencies 


\section{Pendahuluan}

Pendidikan merupakan kegiatan yang sangat kompleks. Hampir seluruh dimensi kehidupan manusia terlibat dalam proses pendidikan. Pendidikan pada hakikatnya usaha untuk mencerdaskan kehidupan manusia atau proses memanusiakan manusia yang diselenggarakan melalui proses pendidikan. Pendidikan adalah proses interaksi yang bertujuan. Interaksi terjadi antara guru dengan siswa yang bertujuan meningkatkan perkembangan mental sehingga menjadi mandiri yang utuh (Dimyati dan Mudjiono, 2015). Menurut Sirait (2017) Pendidikan merupakan faktor yang sangat penting bagi kehidupan manusia. Melalui pendidikan, manusia akan tumbuh dan berkembang sebagai pribadi yang utuh. Maju-mundurnya proses pengembangan suatu bangsa di segala bidang sangat ditentukan oleh tingkat pendidikan bangsa itu sendiri. Oleh sebab itu, pengembangan sektor pendidikan harus menjadi prioritas.

Undang - Undang No 20 Tahun 2003 Tentang Sistem Pendidikan Nasional menyatakan, pendidikan adalah usaha sadar dan terencana untuk mewujudkan suasana belajar dan proses pembelajaran agar peserta didik secara aktif mengembangkan potensi dirinya untuk memiliki kekuatan spiritual keagamaan, pengendalian diri, kepribadian, kecerdasan, akhlak mulia, dan keterampilan yang diperlukan dirinya, masyarakat, bangsa, dan negara.

Melalui pendidikan yang baik dan berkualitas, generasi penerus bangsa akan mendapatkan pengalaman, keterampilan dan ilmu pengetahuan yang berharga. Untuk mencapai pendidikan yang bermutu dan berkualitas maka pendidikan harus direncanakan dan dilaksanakan dengan sebaik - baiknya secara optimal. Oleh karena itu pemerintah telah menyelenggarakan pembaharuan dan pengembangan untuk meningkatkan mutu pendidikan di Indonesia. Satu diantaranya yaitu dengan melakukan penyempurnaan dan pengembangan pada kurikulum pendidikan.

Undang - Undang Nomer 20 Tahun 2003 Tentang Sistem Pendidikan Nasional menyebutkan bahwa kurikulum adalah seperangkat rencana dan pengaturan mengenai tujuan, isi dan bahan pelajaran serta cara yang digunakan sebagai pedoman penyelenggaraan kegiatan pembelajaran untuk mencapai tujuan pendidikan tertentu.

Kurikulum yang diimplementasikan di Indonesia saat ini yaitu Kurikulum 2013. Kurikulum ini merupakan penyempurnaan dan pengembangan dari Kurikulum Tingkat Satuan Pendidikan (KTSP). Kurikulum 2013 diterapkan dengan menelaah Standar Kompetensi Lulusan (SKL), Kompetensi Inti (KI) dan Kompetensi Dasar (KD) secara benar. Kurikulum 2013 menekankan pada pentingnya pembentukan karakter siswa di sekolah, terutama pada pendidikan dasar. Standar kompetensi lulusan yang dirumuskan dalam kurikulum 2013 secara umum yang terkait dengan sikap perilaku. Implementasi kurikulum 2013 secara benar dipercaya dapat mengatasi permasalahan sumber daya manusia di Negara kita. Namun, terdapat kesulitan dalam penerapan kurikulum karena keterbatasan pengetahuan dan wawasan guru terkait dengan konsep pembelajaran dan penilaian yang ditetapkan (Ridwan, 2015). Agar dapat mencapai tujuan yang diharapkan, disinilah peran para guru yang menjadi ujung tombak dalam kurikulum dan pendidikan untuk mendidik, mengajar dan melatih peserta didik agar menjadi generasi penerus bangsa yang berkualitas.

Menurut Rusman (2015:230) "guru adalah pencipta kondisi lingkungan belajar bukan sebagai transformator yang hanya menyuapi dan menjejali siswa dengan informasi yang kurang bermakna". Guru merupakan salah satu faktor penentu keberhasilan dalan setiap upaya pendidikan. Untuk mencapai faktor penentu keberhasilan tersebut dalam proses pembelajaran dikelas diantaranya yaitu strategi guru dalam mengajar yaitu dalam memvariasikan model pembelajaran, metode dan media pembelajaran sebagai pendukung proses pembelajaran. Guru harus mampu mengidentifikasi perbedaan karakteristik peserta didik dengan berbagai potensi yang ada pada diri peserta didik, maka akan mampu membangun komunikasi yang baik dengan peserta didik dan dapat menentukan tindakan yang tepat untuk memotivasi siswa (Kunandar, 2014). Peran guru juga sebagai pengajar, fasilitator, motivator, pembimbing dalam proses pembelajaran. 
Dalam pembelajaran Kurikulum 2013 pada muatan materi IImu Pengetahuan Alam (IPA) dapat memberi peluang kepada siswa untuk berpartisipasi aktif dalam proses belajar. Menurut Sulistyowati (2014:22) "IPA merupakan rumpun ilmu yang memiliki karakteristik khusus yaitu mempelajari fenomena alam yang faktual (factual), baik berupa kenyataan (reality) atau kejadian (events) dan hubungan sebab-akibatnya". Menurut Wijanarko (2017) Pembelajaran IPA sekolah dasar merupakan pembelajaran yang didalamnya terdapat bayak sekali materi yang berhubungan dengan lingkungan sekitar. Proses pembelajaran IPA seharusnya menjadi proses pembelajaran yang menyenangkan bagi siswa karena ada banyak model maupun media pembelajaran yang dapat digunakan dalam menyampaikan materi IPA. Akan tetapi, guru cenderung masih menggunakan metode ceramah dalam menyampaikan materi dengan alasan agar semua materi dapat tersampaikan. Hal ini menyebabkan siswa merasa jenuh saat proses pembelajaran berlangsung. Oleh karena itu, diperlukan perubahan dalam proses pembelajaran IPA.

Berdasarkan observasi dan wawancara pada tanggal 14 Januari 2019 dengan guru kelas IV di semua SD Gugus III Kuta Utara, bahwa penguasaan kompetensi pengetahuan IPA kelas IV SD Gugus III Kuta Utara masih belum mencapai target Kriteria Ketuntasan Minimal (KKM). Dimana KKM untuk kompetensi pengetahuan IPA yang diharapkan dalam kurikulum 2013 adalah 73,00. Hasil tersebut dilihat dari nilai Ulangan Akhir Semester (UAS) siswa semester ganjil dari 518 siswa yang ada di SD Gugus III Kuta Utara, 97 siswa mendapatkan predikat (A), 138 siswa mendapatkan predikat (B), 140 siswa mendapatkan predikat (C), 143 siswa mendapatkan predikat (D). Dari 518 siswa kelas IV sebanyak 235 siswa yang sudah mencapai KKM, sedangkan 283 siswa yang belum mencapai KKM. Hal ini disebabkan, kurangnya daya tarik siswa terhadap suatu pembelajaran dan tidak adanya partisipasi aktif antara siswa dengan guru dalam pelaksanaan pembelajaran berlangsung, kurangnya variasi model pembelajaran yang digunakan saat proses pembelajaran, serta kurangnya penggunaan media pembelajaran untuk mendukung keaktifan siswa. Hal - hal tersebut menyebabkan siswa menjadi jenuh dan cepat bosan dalam mengikuti pembelajaran sehingga berdampak pada kompetensi pengetahuan IPA siswa yang belum optimal.

Berdasarkan uraian permasalahan tersebut, maka diperlukan adanya suatu inovasi pembelajaran yang dapat mengaktifkan siswa dalam pembelajaran dan membuat pembelajaran lebih menyenangkan sehingga pembelajaran tersebut menjadi lebih bermakna bagi siswa. Salah satu inovasi pembelajaran yang dapat dilakukan adalah dengan menggunakan model pembelajaran Make A Match (Membuat Pasangan).

Model pembelajaran Make $A$ Match merupakan model pembelajaran yang dikembangkan oleh Lorna Curran. Ciri utama model Make $A$ Match adalah siswa diminta mencari pasangan kartu yang merupakan jawaban atau pertanyaan materi tertentu dalam pembelajaran (Soimin, 2014). Menurut Mikran (2014) Metode Make A Match merupakan metode belajar mengajar mencari pasangan dimana siswa mencari pasangan sambil belajar mengenai suatu konsep atau topik dalam suasana yang menyenangkan. Jumlah siswa dalam satu kelompok tidak boleh terlalu besar, yang terdiri dari 2 orang atau lebih. Hal ini dimaksud agar proses kerjasama antar siswa berjalan efektif, sehingga memungkinkan semua siswa terlibat secara aktif dalam pembelajaran untuk membahas dan memecahkan masalah. Menurut Wandy (2017) Model pembelajaran kooperatif tipe Make A Match ini menempatkan siswa pada posisi sangat dominan dalam proses pembelajaran dimana semua siswa dalam setiap kelompok diharuskan untuk berusaha memahami dan menguasai materi yang sedang diajarkan dan selalu aktif ketika kerja kelompok sehingga saat di tunjuk untuk mempresentasikan jawabannya, mereka dapat menyumbangkan skor bagi kelompoknya. Metode pembelajaran ini dapat menciptakan suasana pembelajaran yang aktif sehingga akan berdampak terhadap peningkatan hasil belajar siswa. Menurut Aliputri (2018) Pada model pembelajaran kooperatif tipe Make $A$ Match terlebih dahulu diadakan latihan kerjasama kelompok. Hal ini bertujuan untuk mengenal dan memahami karakteristik masingmasing individu dan kelompok. Menurut Kurniasih (2017:55) mengemukakan "model pembelajaran Make A Match mengajak siswa mencari pasangan sambil belajar mengenai suatu konsep atau topik dalam suasana yang menyenangkan". Model pembelajaran ini menitikberatkan permasalah pemain kepada siswa, topik permasalahan yang tepat pada 
kartu soal maupun kartu jawaban akan disajikan langsung oleh guru. Pada teknik permainan ini akan membentuk menjadi dua kelompok dengan ketentuan sebagai pemegang kartu pertanyaan dan kartu jawaban, jika terdapat salah satu siswa yang tidak mendapat pasangan tentunya permainan akan terus berulang agar semua siswa dapat mencobanya.

Agar model pembelajaran Make A Match ini dapat terlaksana dengan menarik dan efektif, model ini dapat divariasikan dengan menggunakan media. Penggunaan media dalam proses pembelajaran dapat membantu menarik perhatian siswa dan membuat siswa menjadi lebih aktif dalam proses pembelajaran. Salah satu media pembelajaran yang dapat diaplikasikan dengan model pembeljaaran Make $A$ Match adalah media Audio Visual. Menurut Wati (2016:5) "media audio visual merupakan media yang dapat menampilkan unsur gambar dan suara secara bersamaan pada saat mengomunikasika pesan atau informasi". Penggunaan media ini dalam proses pembelajaran diselingi tayangan video yang berkaitan dengan materi yang dipelajari untuk menambah pemahaman siswa akan materi tersebut. Dengan situasi yang menyenangkan dan peran aktif siswa dalam proses pembelajaran siswa lebih mudah dalam menerima dan memahami materi pembelajaran sehingga kompetensi pengetahuan diperoleh secara optimal.

Berdasarkan uraian tersebut, maka dilakukan penelitian dengan judul Pengaruh Model Pembelajaran Make A Match Berbantuan Media Audio Visual terhadap Kompetensi Pengetahuan IPA Kelas IV SD Gugus III Kuta Utara Tahun Ajaran 2018/2019.

\section{Metode}

Penelitian ini dilaksanakan pada semester 2 tahun ajaran 2018/2019 di kelas IV SD Gugus III Kuta Utara.

Rancangan atau desain penelitian adalahrencana dan struktur penelitian yang disusun sedemikian rupa, sehingga kita dapat memperoleh jawaban atas permasalahan permasalahan penelitian (Setyosari, 2015). Jenis penelitian yang dilakukan dalam penelitian ini adalah penelitian kuantitatif dengan desain eksperimen yaitu quasi eksperimental design. Menurut Sugiyono (2015:114) "desain ini mempunyai kelompok kontrol, tetapi tidak dapat berfungsi sepenuhnya untuk mengontrol variabel - variabel luar yang mempengaruhi pelaksanaan eksperimen". Rancangan Eksperimen Kuasi yang digunakan adalah Nonequivalent Control Group Design.

\begin{tabular}{|cccl|}
\hline 01 & $X$ & 02 & (eksperimen) \\
\hdashline 03 & & 04 & (kontrol) \\
\hline
\end{tabular}

Gambar 1. Rancangan Penelitian Nonequivalent Control Grup Design

Keterangan:
O1 = Pre test pada kelompok eksperimen
$\mathrm{O} 2=$ Post test pada kelompok eksperimen
O3 = Pre test pada kelompok kontrol
$\mathrm{O} 4=$ Post test pada kelompok kontrol
$\mathrm{X}=$ Perlakuan yang diberikan pada kelompok eksperimen

Dalam rancangan ini, terdapat dua kelompok yaitu kelompok eksperimen dan kelompok kontrol. Kelompok pertama merupakan kelompok eksperimen yang mendapatkan perlakuan model pembelajaran make a match berbantuan media audio visual serta kelompok kedua merupakan kelompok kontrol yang dibelajarkan dengan pendekatan saintifik. 
Pelaksanaan penelitian ini terdiri dari tiga tahapan yaitu, tahap persiapan eksperimen, tahap pelaksanaan eksperimen, dan tahap akhir eksperimen. (1) tahap persiapan eksperimen, kegiatan yang dilaksanakan yakni (a) melaksanakan observasi di SD Gugus III Kecamatan Kuta Utara untuk mengetahui jumlah siswa setiap sekolah, kondisi siswa dan pembelajaran yang berlangsung, (b) menyusun dan mengkonsultasikan instrumen penelitian pre test dan post test bersama wali kelas dan dosen pembimbing, (c) mengadakan uji coba instrumen penelitian, (d) menganalisis instrumen penelitian, (e) menyusun dan mengkonsultasikan RPP (Rencana Pelaksanaan Pembelajaran), LKS, dan media pembelajaran yang akan digunakan dalam proses pembelajaran bersama wali kelas dan dosen pembimbing, (f) menentukan sampel penelitian berupa kelas dari populasi yaitu dengan teknik random sampling, (g) memberikan pre test kepada sampel yang telah diundi untuk membuktikan kesetaraan kelompok, (h) melakukan pengundian untuk menentukan kelompok eksperimen dan kelompok kontrol. (2) tahap pelaksanaan eksperimen, kegiatan yang dilaksanakan yakni: (a) memberikan perlakukan pada kelompok eksperimen berupa pembelajaran dengan model Make A Match berbantuan media audio visual, (b) memberikan pembelajaran pada kelompok kontrol sesuai dengan RPP yang telah direncanakan oleh guru, (c) perlakuan diberikan sebanyak 6 kali pada kelompok eksperimen dan 6 kali pada kelompok kontrol dengan menyesuaikan jam pelajaran. (3) tahap akhir eksperimen, Pada tahap akhir eksperimen ini, kegiatan yang dilaksanakan yakni: (a) memberian post test pada akhir eksperimen, baik untuk kelompok eksperimen maupun kelompok kontrol, (b) menganalisis data hasil penelitian, (c) melakukan uji hipotesis.

Menurut Sugiyono (2015:117) "populasi adalah wilayah generalisasi yang terdiri atas: obyek/subyek yang mempunyai kualitas dan karakteristik tertentu yang ditetapkan oleh peneliti untuk dipelajari dan kemudian ditarik kesimpulannya. Sedangkan menurut Setyosari (2015:221) "populasi merupakan keseluruhan dari objek, orang, peristiwa, atau sejenisnya yang menjadi perhatian dan kajian dalam penelitian". Populasi adalah keseluruhan objek dalam suatu penelitian (Agung, 2014). Jadi dapat disimpulkan pengertian populasi adalah kumpulan dari orang yang memiliki karakteristik tertentu yang ingin diteliti oleh peneliti untuk dipelajari dan ditarik kesimpulannya. Populasi dari penelitian ini adalah seluruh kelas IV di SD Gugus III Kuta Utara.

Menurut Sugiyono (2015:118) "Sampel adalah bagian dari jumlah dan karakteriktik yang dimiliki oleh populasi tersebut. Sedangkan menurut Setyosari (2015:221) "sampel merupakan suatu kelompok yang lebih kecil atau bagian dari populasi secara keseluruhan". Sampel ialah sebagian dari populasi yang diambil, yang dianggap memiliki seluruh populasi dan diambil dengan menggunakan teknik tertentu (Agung, 2014). Dari penjelasan tentang sampel tersebut dapat disimpulkan bahwa sampel adalah bagian dari populasi yang dipilih untuk sumber data. Pengambilan sampel harus memenuhi syarat representatif, artinya sampel yang diambil benar - benar mewakili populasi yang ada (Setyosari, 2015).

Teknik pengambilan sampel pada penelitian ini adalah dengan teknik random sampling. Agung (2014:71) "sampling random merupakan cara pengambilan sampel dengan memberikan kesempatan yang sama kepada anggota populasi untuk diambil menjadi anggota sampel". Cara yang dilakukan dalam random sampling ini adalah dengan menggunakan undian yaitu pengundian kelas. Kemudian dilakukan pengundian dan didapat dua kelas yaitu kelas IV SD No. 2 Kerobokan dan kelas IV A SD No. 1 Kerobokan Kaja. Selanjutnya kedua kelas diberikan pretest dan hasilnya dianalisis dengan uji $t$ untuk mengetahui kesetaraan kedua kelas tersebut. Sebelum dilakukan uji kesetaraan kelas dari seluruh anggota populasi dengan uji-t, terlebih dahulu dilakukan uji prayarat analisis yakni dengan melakukan uji normalitas sebaran data menggunakan rumus Kolmogorov-smirnov dan uji homogenitas dengan menggunakan uji F. Setelah itu dilakukan pengundian lagi untuk menentukan kelas sebagai kelompok eksperimen dan kelompok kontrol.setelah dilakukan pengundian, didapatkan kelas yang menjadi kelompok eksperimen adalah kelas IV SD No. 2 Kerobokan dan kelas IV A SD No. 1 Kerobokan Kaja sebagai kelompok kontrol.

"Validitas penelitian adalah kemampuan suatu penelitian untuk mengungkapkan secara tepat mengenai apa yang ingin diteliti" (Dantes, 2017:3). Validitas yang terkait dengan penelitian yang dilakukan, yaitu validitas internal dan validitas eksternal. 
Salah satu faktor yang dapat mempengaruhi hasil penelitian adalah adanya validitas internal. Setyosari (2015:180) menyatakan "cara yang tepat untuk menentukan validitas internal adalah dengan cara mengidentifikasi dan mengesampingkan sebanyak mungkin perlakuan terhadap validitas internal". Perlakuan ini adalah faktor-faktor dan kondisi selain perlakuan yang telah ditentukan secara terencana, yang dapat memberikan pengaruh terhadap variabel hasil. Validitas internal menyangkut apakah variabel bebas benar-benar menyebabkan pengaruh terhadap variabel terikat (yang diobservasi).

Selain faktor internal, ada faktor lain yang bersifat eksternal yang memiliki pengaruh pada hasil penelitian yaitu validitas eksternal. Setyosari (2015:192) menyatakan "validitas eksternal penelitian mengacu pada sejauh mana suatu hasil penelitian dapat digeneralisasikan". Pengendalian terhadap ancaman tersebut dilakukkan dengan membatasi penelitian pada kelas IV SD Gugus III Kuta Utara. Selain itu untuk mengendalikan ancaman ini juga dapat dilakukan dengan pemilihan anggota sampel secara acak untuk mewakili populasi. Teknik yang digunakan adalah teknik random sampling dengan melakukan pengundian pada populasi yang sudah terbentuk dalam kelas - kelas, sehingga setiap kelas dalam populasi memiliki kesempatan yang sama untuk dijadikan sampel penelitian, sehingga hasilnya dapat digeneralisasikan pada populasi yaitu siswa kelas IV Gugus III Kuta Utara.

Pengumpulan data dalam penelitian ini adalah data tentang kompetensi pengetahuan IPA kelas IV SD Gugus III Kuta Utara. Menurut Sugiyono (2017:137) "pengumpulan data dapat dilakukan dengan berbagai setting, berbagai sumber, dan berbagai cara". Secara garis besar metode pengumpulan data dapat dibedakan menjadi 2 (dua) jenis, yaitu metode tes dan metode non tes. Untuk mengumpulkan data kompetensi pengetahuan tersebut digunakan metode tes. Metode tes dalam kaitannya dengan penelitian ini ialah cara memperoleh data yang berbentuk suatu tugas yang harus dikerjakan oleh seorang atau sekelompok orang yang dites (testee), dan dari tes dapat menghasilkan suatu skor (interval) (Agung, 2014). Instrumen yang digunakan untuk mengetahui kompetensi pengetahuan IPA siswa berupa butir tes yang dikemas menjadi satu perangkat tes yaitu tes kompetensi pengetahuan IPA. Menurut Arikunto (2015:67) "tes merupakan alat atau prosedur yang digunakan untuk mengetahui atau mengukur sesuatu dalam suasana, dengan cara dan aturan - aturan yang sudah ditentukan". Pada penelitian ini jenis tes yang digunakan adalah tes objektif pilihan ganda biasa dengan 4 pilihan jawaban (A, B, C, atau D) yang mengandung satu jawaban yang benar. Setiap butir tes diberikan skor 1 bila siswa menjawab benar dan skor 0 bila siswa menjawab salah. Setelah instrument penelitian tersusun kemudian dilakukan uji coba instrument penelitian. Kompetensi pengetahuan yang dikembangkan dalam penelitian ini terdiri dari 34 butir soal. Uji coba instrument yang dilakukan adalah uji validitas empirik oleh pendapat ahli (judgment experts) yang selanjutnya dianalisis dengan uji validitas, uji daya beda, uji tingkat kesukaran, dan uji reliabilitas.

Selanjutnya pelaksanaan penelitian dilakukan dengan perlakuan terhadap masing kelompok sampel yakni model pembelajaran Make A Match berbantuan media Audio Visual pada kelompok eksperimen dan pembelajaran konvensional pada kelompok kontrol. Setelah diberikan perlakuan, kedua kelompok sampel tersebut diberikan posttest. Hal tersebut dilakukan untuk memperoleh kompetensi pengetahuan IPA. Data yang digunakan untuk melakukan analisis pada penelitian ini adalah data gain skor yang dinormalisasi dari hasil pretest dan hasil posttest yang telah didapatkan. Dalam hal ini nilai pretest juga digunakan untuk mengetahui kemampuan awal siswa. Nilai pretest dan posttest diambil dari sampel penelitian, yaitu kelas eksperimen dan kelas kontrol yang dinormalisasikan dengan menggunakan rumus gain skor ternormalisasi sebagai berikut.

Rumus Gain Skor Ternormalisasi

$$
\text { GS } n=\frac{\text { Gain Skor }}{\text { Skor max }- \text { Skor pre test }}
$$


Keterangan :

GSn $\quad=$ Gain skor ternormalisasi

Gain Skor = Skor post test - skor pre test

Skor max = Skor maksimal ideal

Metode analisis data yang digunakan dalam penelitian kuantitatif adalah metode analisis statistik. Metode analisis statistik yang digunakan dalam penelitian ini adalah metode analisis statistik inferensial.

Menurut Agung (2014:110) "analisis statistik inferensial ialah cara pengolahan data yang dilakukan dengan jalan menerapan rumus - rumus statistik inferensial untuk menguji suati hipotesis penelitian yang diajuan peneliti dan kesimpulan ditari berdasarkan hasil pengujian terhadap hipotesis".

Kemudian nilai postest tersebut diuji dengan uji prasyarat analisis data yang meliputi uji normalitas dan uji homogenitas. Uji normalitas dilakukan untuk mengetahui apakah sebaran data skor kompetensi pengetahuan IPA masing-masing kelompok berdistribusi normal atau tidak dengan menggunakan rumus Kolmogorov-Smirnov. Sedangkan uji homogenitas dilakukan untuk menunjukkan bahwa perbedaan yang terjadi pada uji hipotesis benar terjadi akibat adanya perbedaan antar kelompok, bukan sebagai akibat perbedaan individu dalam kelompok dengan menggunakan uji F. Setelah uji prasyarat dilakukan kemudian dilanjutkan dengan pengujian hipotesis. Hipotesis yang diuji adalah hipotesis nol $(\mathrm{H} 0)$ yang berbunyi: "tidak terdapat perbedaan yang signifikan kompetensi pengetahuan IPA kelompok yang dibelajarkan menggunakan model pembelajaran Make $A$ Match berbantuan media Audio Visual dan kelompok yang dibelajarkan menggunakan pembelajaran konvensional pada kelas IV SD Gugus III Kuta Utara tahun ajaran 2018/2019. Teknik analisis data yang digunakan untuk menguji hiopotesis dalam penelitian ini adalah uji-t dengan rumus polled varians.

Rumus uji-t dengan polled varian sebagai berikut.

$$
t=\frac{\overline{X_{1}}-\overline{X_{2}}}{\sqrt{\frac{\left(n_{1}-1\right) s_{1}^{2}+\left(n_{2}-1\right) s_{2}{ }^{2}}{n_{1}+n_{2}-2}\left(\frac{1}{n_{1}}+\frac{1}{n_{2}}\right)}}
$$

(Sugiyono, 2017:197)

Keterangan :

$$
\begin{array}{ll}
\bar{X}_{1} & =\text { Rata-rata gain skor ternomalisasi sampel } 1 \\
\bar{X}_{2} & =\text { Rata-rata gain skor ternomalisasi sampel } 2 \\
\mathrm{~s}_{1}{ }^{2} & =\text { Varian sampel } 1 \\
\mathrm{~s}_{2}{ }^{2} & =\text { Varian sampel } 2 \\
\mathrm{n}_{1} & =\text { Jumlah sampel } 1 \\
\mathrm{n}_{2} & =\text { Jumlah sampel } 2
\end{array}
$$

Pada taraf signifikansi $5 \%$ dengan $\mathrm{dk}=\mathrm{n}_{1}+\mathrm{n}_{2}-2$, kriteria pengujiannya yaitu jika $t_{\text {hitung }} \leq$ $t_{\text {tabel }}$, maka Ho diterima dan Ha ditolak, sehingga kelompok setara. Jika harga $t_{\text {hitung }}>t_{\text {tabel }}$ maka Ho ditolak dan Ha diterima, sehingga kelompok tidak setara. 


\section{Hasil dan Pembahasan}

Kelompok eksperimen dalam penelitian ini adalah kelas IV di SD No. 2 Kerobokan sebanyak 39 siswa. Pada kelompok eksperimen, setelah diberikan pretest maka dilanjutkan dengan pemberian perlakuan dengan model pembelajaran Make A Match Berbantuan Media Audio Visual sebanyak 6 kali. Pada akhir penelitian siswa diberikan posttest untuk memperoleh data kompetensi pengetahuan IPA. Setelah memperoleh nilai posttest kemudian diari gain skor yang dinormalisasikan dari hasil pretest dan posttest. Berdasarkan hasil analisis, kompetensi pengetahuan IPA kelompok eksperimen diperoleh nilai rata - rata gain skor ternormalisasi $\bar{X}=0,52$.

Kelompok kontrol dalam penelitian ini adalah kelas IV A di SD No. 1 Kerobokan Kaja sebanyak 33 siswa. Setelah diberikan pretest, pelaksanaan pembelajaran di kelompok kontrol berlangsung secara konvensional atau pembelajaran seperti biasanya dan diamati sebanyak 6 kali. Pada akhir penelitian siswa diberikan posttest untuk memperoleh data kompetensi pengetahuan IPA. Setelah memperoleh nilai posttest kemudian diari gain skor yang dinormalisasikan dari hasil pretest dan posttest. Berdasarkan hasil analisis, kompetensi pengetahuan IPA kelompok kontrol diperoleh nilai rata - rata gain skor ternormalisasi $\bar{X}=$ 0,32 .

Sesuai dengan hasil analisis data kompetensi pengetahuan IPA menunjukkan bahwa rata - rata gain skor ternormalisasi kompetensi pengetahuan IPA kelompok eksperimen $\bar{X}=$ $0,52>\bar{X}=0,32$ rata - rata gain skor kompetensi pengetahuan IPA kelompok kontrol. Rangkuman hasil perhitungan uji normalitas sebaran data gain skor ternormalisasi kompetensi pengetahuan IPA disajikan pada Tabel 1.

Tabel 1. Hasil Uji Normalitas Sebaran Data Gain Skor

\begin{tabular}{ccccc}
\hline No & Sampel & $\begin{array}{c}\text { Nilai } \\
\text { Maksimum } \\
\mathbf{F t}-\mathbf{F s} \mid\end{array}$ & $\begin{array}{c}\text { Nilai Tabel } \\
\text { Kolmogorov-Smirnov }\end{array}$ & Keterangan \\
\hline 1 & Kelompok Eksperimen & 0,137 & 0,213 & Normal \\
2 & Kelompok Kontrol & 0,175 & 0,231 & Normal \\
\hline
\end{tabular}

Berdasarkan analisis data yang dilakukan, rangkuman hasil uji normalitas sebaran data kelompok eksperimen dan kelompok kontrol menunjukkan bahwa nilai maksimum| Ft Fs $\mid$ < nilai tabel Kolmogorov-smirnov yakni pada kelompok eksperimen nilai maksimum $\mid \mathrm{Ft}$ - Fs| diperoleh 0,137 dibandingkan nilai tabel Kolmogorov-smirnov diperoleh 0,213 sedangkan pada kelompok kontrol nilai maksimum $\mid \mathrm{Ft}$ - Fs $\mid$ diperoleh 0,175 dibandingkan dengan nilai tabel Kolmogorov-smirnov sebesar 0,231. Maka HO diterima ini berarti kedua data berdistribusi normal.

Setelah uji normalitas sebaran data dilakukan, selanjutnya dilakukan uji homogenitas varian data pretest kompetensi pengetahuan IPA. Adapun rekapitulasi hasil uji homogenitas varian dengan menggunakan uji $\mathrm{F}$. Rangkuman hasil perhitungan uji homogenitas varians kelompok eksperimen dan kelompok kontrol disajikan pada Tabel 2.

Tabel 2. Hasil Uji Homogenitas Varians Kelompok Eksperimen dan Kelompok Kontrol

\begin{tabular}{clccccc}
\hline No & \multicolumn{1}{c}{ Sampel } & Varian & $\mathbf{d k}$ & $\mathbf{F}_{\text {hitung }}$ & $\mathbf{F}_{\text {tabel }}$ & Keterangan \\
\hline 1 & Kelompok Eksperimen & 0,03 & 38 & 1,50 & \multirow{2}{*}{1,78} & \multirow{2}{*}{ Homogen } \\
2 & Kelompok Kontrol & 0,02 & 32 & & & \\
\hline
\end{tabular}

Selanjutnya dilakukan uji homogenitas terhadap varians antar kelompok eksperimen dan kelompok kontrol. Uji homogenitas varians dalam penelitian ini menggunakan uji $F$ dengan kriteria data homogen jika Fhitung < Ftabel. Berdasarkan analisis data yang dilakukan, rangkuman hasil uji homogenitas data kelompok eksperimen dan kelompok 
kontrol menunjukkan bahwa $F_{\text {hitung }}$ kompetensi pengetahuan IPA adalah 1,50 sedangkan $F_{\text {tabel }}$ sebesar 1,78 dengan derajat kebebasan untuk pembilang n1-1 $(39-1=38)$ dan derajat kebebasan untuk penyebut n2-1 $(33-1=32)$ dan taraf signifikan $5 \%$. Hal ini berarti varians data kompetensi pengetahuan IPA kelompok eksperimen dan kelompok kontrol adalah homogen.

Berdasarkan hasil uji normalitas dan uji homogenitas varians diperoleh data kedua kelompok yaitu kelompok yang dibelajarkan menggunakan model pembelajaran Make $A$ Match berbantuan media audio visual dan kelompok yang dibelajarkan menggunakan pembelajaran konvensional berdistribusi normal dan varian kedua kelompok homogen. Setelah diperoleh hasil dari uji prasyarat analisis data, kemudian dilanjutkan pengujian hipotesis. Uji hipotesis tersebut dilakukan melalui uji beda mean (uji-t) dengan rumus polled varians. Dengan kriteria pengujian jika $t_{\text {hitung }}<t_{\text {tabel, }}$ maka Ho diterima dan Ha ditolak, dan jika harga $t_{\text {hitung }}>t_{\text {tabel }}$, maka Ho ditolak dan Ha diterima. Pada taraf signifikansi $5 \%(\alpha=0,05)$ dengan ( $\mathrm{dk}=\mathrm{n} 1+\mathrm{n} 2-2)$. Rangkuman hasil analisis uji-t data kompetensi pengetahuan IPA disajikan pada Tabel 3.

Tabel 3. Hasil Analisis Uji-t Data Kompetensi Pengetahuan IPA

\begin{tabular}{clccccc}
\hline No & Kelompok Sampel & $\mathbf{N}$ & $\mathbf{d k}$ & $\mathbf{X}$ & $\mathbf{t}_{\text {hitung }}$ & $\mathbf{t}_{\text {tabel }}$ \\
\hline 1 & Eksperimen & 39 & 70 & 0,52 & 5,128 & 2,000 \\
2 & Kontrol & 33 & & 0,32 & \\
\hline
\end{tabular}

Berdasarkan Tabel di atas, dapat dilihat bahwa $t_{\text {hitung }}$ lebih besar dari pada $t_{\text {tabel }}$ yaitu $5,128>2,000$. Dengan hasil tersebut maka dapat disimpulkan bahwa Ho yang berbunyi "tidak terdapat perbedaan yang signifikan kompetensi pengetahuan IPA antara kelompok yang dibelajarkan menggunakan model pembelajaran Make $A$ Match berbantuan media Audio Visual dan kelompok yang dibelajarkan menggunakan pembelajaran konvensional pada kelas IV SD Gugus III Kuta Utara Tahun Ajaran 2018/2019", ditolak dan Ha yang berbunyi "terdapat perbedaan yang signifikan kompetensi pengetahuan IPA antara kelompok siswa yang dibelajarkan menggunakan model pembelajaran Make $A$ Match berbantuan media Audio Visual dan kelompok siswa yang dibelajarkan menggunakan pembelajaran konvensional pada kelas IV SD Gugus III Kuta Utara Tahun Ajaran 2018/2019", diterima. Hal tersebut diperkuat oleh rerata kompetensi pengetahuan IPA kelompok eksperimen adalah 0,52 lebih dari kelompok kontrol adalah 0,32. Hal ini model pembelajaran Make $A$ Match berbantuan media audio visual lebih baik dalam mengoptimalkan kompetensi pengetahuan IPA dibandingkan dengan pembelajaran konvensional.

Berdasarkan hasil analisis menggunakan uji-t diperoleh thitung $=5,128$, kemudian dibandingkan dengan $t_{\text {tabel }}$ dengan $\mathrm{dk}=70$ pada taraf signifikansi $5 \%$ diperoleh $t_{\text {tabel }}=2,000$. Karena $t_{\text {hitung }}=5,128>t_{\text {tabel }}=2,000$, maka Ho ditolak. Hal ini berarti terdapat perbedaan yang signifikan terhadap kompetensi pengetahuan IPA kelompok yang dibelajarkan menggunakan model pembelajaran Make A Match berbantuan media Audio Visual dan kelompok yang dibelajarkan menggunakan pembelajaran konvensional pada kelas IV SD Gugus III Kuta Utara tahun ajaran 2018/2019. Perolehan hasil perhitungan analisis data menunjukkan bahwa rata - rata gain skor kompetensi pengetahuan IPA kelompok yang mengikuti pembelajaran menggunakan model pembelajaran Make $A$ Match berbantuan media Audio Visual adalah 0,52 dan rata - rata gain skor kompetensi pengetahuan IPA kelompok yang mengikuti pembelajaran secara konvensional adalah 0,32. Rata - rata gain skor ternormalisasi yang diperoleh bahwa kelompok eksperimen memiliki rata - rata lebih tinggi daripada kelompok kontrol. Berdasarkan perolehan nilai kompetensi pengetahuan IPA pada kelompok eksperimen dan kelompok kontrol dapat diketahui bahwa kedua kelompok yang awalnya memiliki kemampuan yang setara, kemudian setelah diberi perlakuan pada kelompok eksperimen dengan model pembelajaran Make A Match berbantuan media Audio Visual maka perolehan nilai kompetensi pengetahuan IPA kedua kelompok tersebut mengalami perbedaan. Kompetensi pengetahuan IPA pada kelompok eksperimen lebih baik apabila dibandingkan dengan kompetensi pengetahuan IPA pada kelompok kontrol. Hal ini 
disebabkan oleh perlakuan yang diterapkan dalam proses pembelajaran yaitu menggunakan model pembelajaran Make A Match berbantuan media Audio Visual pada kelompok eksperimen. Model pembelajaran Make A Match berbantuan media Audio Visual terdiri dari lima fase, yaitu (1) penyampaian materi, (2) pembagian kelompok, (3) pembagian permasalahan, (4) mendiskusikan permasalahan, (5) presentasi kelompok.

Pada kegiatan pembelajaran di kelompok eksperimen dengan model pembelajaran Make A Match berbantuan media Audio Visual dapat meningkatkan motivasi diri dalam siswa dan mampu mendorong siswa berinteraksi karena dalam model pembelajaran ini selain belajar siswa juga diajak bermain sambil belajar dalam kelompok. Hal ini sejalan dengan pendapat Kurniasih dan Berlin (2017) yang mengemukakan beberapa kelebihan model pembelajaran Make $A$ Match yaitu : (1) mampu menciptakan suasana belajar aktif dan menyenangkan, (2) materi pembelajaran yang disampaikan lebih menarik perhatian siswa, (3) mampu meningkatkan hasil belajar siswa menapai taraf ketuntasan belajar secara klasikal, (4) suasa kegembiraan akan tumbuh dalam proses pembelajaran, (5) kerjasama antar sesama siswa terwujud dengan harmonis, dan (6) munculnya dinamika gotong royong yang merata di seluruh siswa.

Hal ini berarti model pembelajaran Make A Match berbantuan media Audio Visual berpengaruh terhadap kompetensi pengetahuan IPA kelas IV SD Gugus III Kuta Utara tahun ajaran 2018/2019.

\section{Simpulan dan Saran}

Berdasarkan hasil analisis uji-t kompetensi pengetahuan IPA kelompok yang dibelajarkan menggunakan model pembelajaran Make $A$ Match berbantuan media Audio Visual dan kelompok yang dibelajarkan secara konvensional pada kelas IV SD Gugus III Kuta Utara tahun ajaran 2018/2019, diperoleh rata - rata kompetensi pengetahuan IPA kelompok eksperimen $\bar{X}_{1} 0,52>\bar{X}_{2}=0,32$ rata - rata kompetensi pengetahuan IPA kelompok kontrol. Hasil analisis uji-t diperoleh $t_{\text {hitung }}=5,128$. Harga tersebut kemudian dibandingkan dengan harga $t_{\text {tabel }}$ dengan $\mathrm{dk}=39+33-2=70$ dan taraf signifikansi $5 \%$ sehingga diperoleh $t_{\text {tabel }}=2,000$ karena $t_{\text {hitung }}=5,128>t_{\text {tabel }}=2,000$ maka Ho ditolak. Hal ini berarti terdapat perbedaan yang signifikan kompetensi pengetahuan IPA kelompok yang dibelajarkan menggunakan model pembelajaran Make $A$ Match berbantuan media Audio Visual dan kelompok yang dibelajarkan secara konvensional pada kelas IV SD Gugus III Kuta Utara tahun ajaran 2018/2019dengan demikian dapat disimpulkan bahwa model pembelajaran Make $A$ Match berbantuan media Audio Visual berpengaruh terhadap kompetensi pengetahuan IPA kelas IV SD Gugus III Kuta Utara tahun ajaran 2018/2019.

Berdasarkan hasil penelitian, maka diajukan beberapa saran kepada beberapa pihak sebagai berikut. 1) Kepada guru, disarankan agar lebih kreatif dalam memberikan fasilitas berupa sumber belajar dan kesempatan yang lebih besar bagi siswa dalam proses pembelajaran dengan menggunakan model - model pembelajaran yang inovatif sehingga tercipta pembelajaran bermakna bagi siswa; 2) Kepada kepala sekolah, disarankan agar dapat menggunakan hasil penelitian ini sebagai pendukung sumber belajar dalam mengembangkan proses pembelajaran dengan menciptakan suasana pembelajaran yang menyenangkan di sekolah, sehingga sekolah mampu menghasilkan output yang berukualitas; 3) Kepada peneliti lain, disarankan agar hasil penelitian ini digunakan sebagai referensi untuk melaksanakan penelitian selanjutnya serta menemukan inovasi dalam merangcang kegiatan pembelajaran lainnya yang bermakna bagi siswa.

\section{Daftar Pustaka}

Agung, A.A Gede. 2014. Buku Ajar Metodologi Penelitian Pendidikan. Yogyakarta: Aditya Media Publishing.

Aliputri, Dhestha Hazilla. 2018. Penerapan Model Pembelajaran Kooperatif Tipe Make A Match Berbantuan Kartu Bergambar Untuk Meningkatkan Hasil Belajar Siswa. Jurnal 
Bidang Pendidikan Dasar (JBPD), Vol.2 No. 1A, Hal. 70-77. Tersedia Pada: http://ejournal.unikama.ac.id/index.php/JBPD/article/view/2351.

Dantes, Nyoman. 2017. Desain Eksperimen dan Analisis Data. Yogyakarta: Andi

Dimyati dan Mudjiono. 2015. Belajar dan Pembelajaran. Jakarta: Rineka Cipta.

Kunandar. 2014. Penilaian Autentik (Penilaian Hasil Belajar Peserta Didik berdasarkan Kurikulum 2013). Jakarta: Rajawali Pers.

Kurniasih, Imas dan Berlin Sani. 2017. Ragam Pengembangan Model Pembelajaran untuk Peningkatan Profesionalitas Guru. Yogyakarta: Kata Pena.

Mikran, Marungkil Pasaribu, I Wayan Darmadi. 2014. Penerapan Model Pembelajaran Kooperatif Make A Match untuk Meningkatkan Hasil Belajar Siswa Kelas VIIA SMP Negeri 1 Tomini Pada Konsep Gerak. Jurnal Pendidikan Fisika Tadulako (JPFT) Vol. 2 No. 2, Hal. 9-16. Tersedia Pada: http://jurnal.untad.ac.id/jurnal/index.php/EPFT/article/view/2781.

Peraturan Menteri Pendidikan dan Kebudayaan Republik Indonesia Nomor 81A Tahun 2013 Tentang Implementasi Kurikulum. 2013. Jakarta: Kementerian Pendidikan dan Kebudayaan.

Ridwan, Abdullah Sani. 2015. Pembelajaran Saintifik untuk Implementasi Kurikulum 2013. Jakarta: Bumi Aksara.

Rusman. 2015. Pembelajaran Tematik Terpadu, Praktik dan Penilaian. Jakarta: Rajawali Pers.

Setyosari, Punaji. 2015. Metode Penelitian Pendidikan dan Pengembangan. Jakarta: Prenadamedia Group.

Shoimin, Aris. 2014. 68 Model Pembelajaran Inovatif dalam Kurikulum 2013. Yogyakarta: Arruzz Media.

Sirait, Makmur, Putri Adilah Noer. 2013. Pengaruh Model Pembelajaran Kooperatif Tipe Make A Match terhadap Hasil Belajar Siswa. Jurnal INPAFI Volume 1, Nomor 3, Hal. 252-259.

Tersedia

Pada: https://jurnal.unimed.ac.id/2012/index.php/inpafi/article/viewFile/1914/7846.

Sulistyowati, Eka dan Asih Widi Wisudawati. 2014. Metodologi Pembelajaran IPA. Jakarta: Bumi Aksara.

Sugiyono. 2015. Metode Penelitian Pendidikan (Pendekatan Kuantitatif, Kualitatif dan R\&D). Bandung: Alfa Beta.

Sugiyono. 2017. Metode Penelitian Pendidikan (Pendekatan Kuantitatif, Kualitatif dan R\&D). Bandung: Alfa Beta.

Undang - Undang Republik Indonesia No. 20 Tahun 2003 tentang Sistem Pendidikan Nasional. 2003. Jakarta: Departemen Pendidikan Nasional. 
Wandy. 2017. Metode Pembelajaran Make A Match untuk Meningkatkan Hasil Belajar Bahasa Indonesia Siswa Sekolah Menengah Pertama. Jurnal Ilmu Pendidikan Sosial, sains, dan Humaniora Vol. 3 No. 1, Hal. 109-116. Tersedia Pada: http://ejournal.uinsuska.ac.id/index.php/suaraguru/article/view/3053.

Wati, Ega Rima. 2016. Ragam Medua Pembelajaran Visual-Audi Visual - Komputer - Power Point - Internet - Interactive Video. Yogyakarta: Kata Pena.

Wijanarko, Yudi. 2017. Model Pembelajaran Make A Match untuk Pembelajaran IPA yang Menyenangkan. Jurnal Taman Cendekia Vol. 01 No. 01 Hal. 52-59. Tersedia Pada: http://jurnal.ustjogja.ac.id/index.php/tamancendekia/article/view/1579/704. 